\title{
Metaphoric Perceptions of the Students of the Sports Sciences Faculty Regarding the Concept of Fair-play
}

\author{
Hakan Salim Çağlayan ${ }^{1}$, Özgür Gül ${ }^{1}$ \\ ${ }^{1}$ Selcuk University, Faculty of Sport Sciences, Konya, Turkey \\ Correspondence: Assistant Professor Özgür GÜL, Selcuk University, Faculty of Sport Sciences, Department of Physical \\ Education and Sport, Konya, Turkey.
}

Received: June 20, 2017

doi:10.11114/jets.v5i8.2502
Accepted: July 16, 2017

Online Published: July 27, 2017

URL:https://doi.org/10.11114/jets.v5i8.2502

\begin{abstract}
The objective of this study is to reveal the perceptions of the students of the sports sciences faculty regarding the concept of "Fair-Play" by means of metaphors. 275 students $\left[\right.$ male $_{(\mathrm{n}=173)}$, female $_{(\mathrm{n}=102)}$ ] studying at the Sports Sciences Faculty of Seljuk University in the fall semester of the 2016-2017 educational year took part in the study voluntarily.

The data of the study were obtained by making the students complete the sentence of "Fair-Play is like............. because.........." Every student was expected to create a metaphor regarding the concept of Fair-Play in that way. In this study, the research design of phenomenology was used and the analysis of the data was conducted by using the content analysis method.

The perceptions of the students of the Sports Sciences Faculty for the concept of "Fair-Play" were scrutinized by way of the metaphor analysis method. In this scope, the process of analysis and construal of the metaphors developed by the students took place in five stages as (1) determination of the metaphors, (2) classification of the metaphors, (3) category development, (4) ensuring validity and reliability, and (5) transfer of the data to the SPSS package program for quantitative data analysis.According to the findings of the study, the students created totally 119 valid metaphors regarding the concept of "Fair-Play."

The metaphors were analyzed in terms of their common traits and brought together under seven conceptual categories. At the end of the study, it was determined that students have perceived Fair Play as the "Expression of Wisdom" by 27\%; as the "Expression of Nature" by 25\%; "as a Guide" by 19\%; as the "Expression of Humanly Qualifications" by $13 \%$; as the "Expression of Cleanness" by 8\%; as the "Expression of Contradiction" by 5\%; and as "Important Persons" by $3 \%$.
\end{abstract}

Keywords: metaphor, fair play, qualitative study

\section{Introduction}

Metaphor is the expression by a person of a concept or phenomenon in the manner that he/she perceives it and by means of using analogy.The word of "Metaphor"that has numerous definitions has been derived from"Metapherein" in Greek. "Meta" means changing and "pherein" carrying (Levine, 2005) and it was used as to mean "taking from a place to another." Metaphor is not only a material of thought, a form of human comprehension, and a verbal figure, but also a figure of thought (Lakoff and Johnson, 2003).

Metaphors (similes, figures of speech) constitute one of the strongest mental tools that structure, steer, and control our thoughts about the formation and functioning of happenings. Metaphors are also defined as the "language of experiences" in view of the fact that they make sense of the personal experiences of individuals (Saban, 2004). With such property of them, metaphors direct our practices, shed light on them, and guide them.

Metaphors allow us to construct high level of abstract and detailed concepts. They are one of the most significant tools of trying to comprehend partially the things that we do not discern entirely, our thoughts, our esthetic experiences, our moral practices, and our spiritual awareness. They provide the opportunity for the deductions to be used within the motor sensory areas and other areas. As we reason according to metaphors, the metaphors we use determine the way how we continue our lives to a large extent (Lakoff and Johnson, 2003). 
Metaphors that attracted the attention of educators in the recent years have been the subject of various studies in the domestic and foreign literature. They were used in encouraging learning, developing and planning creative thought, steering the educational practices, and determining the place of educators in modern understanding of education (Guerrero and Villamil, 2002; Forceville, 2002;Saban, 2004; Saban et al., 2006; Arslan and Bayrakçı, 2006; Öztürk, 2007; Cerit, 2008; Shaw et al., 2008; Saban, 2008; Botha, 2009; Alger, 2009; Saban, 2009;Töremen and Döş, 2009; Aydın and Ünaldı, 2010; Çapan, 2010; Çoşkun, 2010; Döş, 2010; Yıldırım et al., 2011; Kaya, 2011) as tools.

In view of the foregoing information, no study regarding the expression via metaphors of the concept of Fair Play shaping in sports sciences in general and in a sports environment in particular has been encountered, despite the presence of numerous studies in the national and international literature that has the subject matter of various mental images (metaphors) in the educational sciences. On that sense, the study endeavors to provide important contribution to the fulfillment of such a gap within the literature. It is considered for that reason that the study conducted is important as it is a first in the field and it constitutes a source for the metaphoric studies that are currently new for the sports sciences.

\subsection{Purpose of the Study}

The main objective of this study is to reveal the perceptions of the Sports Sciences Faculty students regarding the concept of "Fair-Play" by means of metaphors. Within the framework of this main objective, answers for the following questions have been sought:

1. Which metaphors do the Sports Sciences Faculty students use to explain their perceptions regarding the concept of "Fair-Play?"

2. Which categories can be created to bring together the metaphors asserted by students for the concept of "Fair-Play" in terms of their common properties?

\section{Method}

\subsection{The Design of the Study}

In this study, "phenomenology," one of the designs of qualitative research, has been used. "The design of phenomenology focuses on the phenomena of which we are aware but for which we do not have an in-depth and detailed understanding. Phenomenology creates a ground of study for us with respect to the studies aiming to scrutinize the phenomena that are not completely strange to us but that, at the same time,we do not discern in a complete sense" (Yıldırım and Şimşek, 2006).

\subsection{The Study Group}

275 students studying at the Sports Sciences Faculty of Seljuk University in the fall semester of the 2016-2017 educational year took part in the study voluntarily.

It was determined that $62,9 \%$ of the students taking part in the study were male $_{(\mathrm{n}=173)}, 37,1 \%$ were female ${ }_{(\mathrm{n}=102)}$; that $42,9 \%$ were studying in sports management ${ }_{(\mathrm{n}=118)}, 30,2 \%$ in teacher training school for physical education and sports $(\mathrm{n}=83)$, and $26,9 \%$ in teacher training school for coaching $(\mathrm{n}=74)$; that $38,9 \%$ were in the $4^{\text {th }}$ year ${ }_{(\mathrm{n}=107)}, 26,5 \%$ in $2^{\text {nd }}$ year $(\mathrm{n}=73), 24,7 \%$ in the $3^{\text {rd }}$ year $_{(\mathrm{n}=68)}$, and $9,8 \%$ in the $1^{\text {st }}$ year $_{(\mathrm{n}=27)}$ as students; that $53,1 \%$ of them were active in individual sports $(\mathrm{n}=146)$ (tennis, judo, swimming, taekwondo, wrestling, athletics, halter, box, kick-box, aerobics-step, ice skating, badminton, and cycling) and46,9\% in team sports ${ }_{(\mathrm{n}=129)}$ (basketball, football, volleyball, handball, field hockey, and futsal); and that $81,1 \%$ of them have received no training regarding Fair-Playpreviously $(\mathrm{n}=223)$, while $18,9 \%$ had been subject to such training beforehand ${ }_{(\mathrm{n}=52)}$.

\subsection{Data Collection}

In the study, the Sports Sciences Faculty students have been informed regarding the subject matter and justification of the study receiving consents from the lecturers of their lessons before they started studying in their classes as in the curriculum andforms were distributed to the volunteers and recollected after approximately 30 minutes. In the study, in order to reveal the perceptions of the students regarding the concept of "Fair-Play," each participant was asked to complete the sentence of "Fair-Play is like............. because.........." They were requested to disclose their thoughts by using the foregoing expression and focusing only on a single metaphor. In the metaphor studies, the concept of "like" is generally used to connote the similarity between the subject matter and the source of the metaphor in a clearer manner. In this study, the concept of "because" was also included to make them produce a reasonable cause for their metaphors. The essays written by the students constituted the basic data source of this study as "documents."

\subsection{Analysis and Construal of the Data}

The process of analyzing and construal of the metaphors developed by students took place in the phases of naming, 
classification, category development, ensuring validity and reliability, and transfer of the data to the SPSS package program for quantitative data analysis.

1. Naming Phase: first, a temporary list was created in alphabetical order for the metaphors produced by students. With this in mind, the fact that whether the participants have expressed a particular metaphor in a clear manner in their essays or not was checked. On that stage, the metaphor expressed in the paper of each participant was simply coded (for example, justice, morality, peace, gentlemanliness, and equality, etc.) and the papers that did not contain any metaphor image were marked in order to be disqualified subsequently.

2. Classification Phase: On that stage, the "metaphor analysis" techniques were used to segment each metaphor and analyze its similarities or common properties with other metaphors. For that purpose, the metaphors written down by the students were read and reviewed one by one and each metaphor was analyzed in terms of (1) the subject matter of the metaphor, (2) the source of the metaphor, and (3) the relation between the subject matter and source of the metaphor. In the study, 30 papers were excluded from the scope of the study due to their incompatibility concerning the relation between the subject matter and source of the metaphor and aggregately 245 papers were evaluated. Total 119 valid metaphors were obtained from the 245 papers produced by the students. On that stage, the metaphors were put in an alphabetical order once again and a sample metaphor expression was picked up from the student essays representing each metaphor upon reviewing the raw data for the second time. Accordingly, for each metaphor, a "sample list of metaphors" was created through the compilation of the sample metaphor expressions assumed to represent it in the best way. The list was assessed in relation to two basic objectives: (a) using as a reference source in bringing together the metaphors under a particular category and (b) validating the data analysis process and interpretations of this study.

3. Category Development Phase: On this stage, basically, the metaphors produced by the Sports Sciences Faculty students were analyzed in terms of their common properties regarding the concept of "Fair-Play." During that process, the way of each metaphor for conceptualizing the "Fair-Play" phenomenon was examined by considering the "metaphor list" in particular for the 119 metaphors. For that purpose, each metaphor produced by the Sports Sciences Faculty students was related with a certain theme according to its viewpoint for "Fair-Play" and totally seven conceptual categories were created.

4. Phase of Ensuring Validity and Reliability: in order to ensure the reliability of the study, an expert opinion was applied to confirm whether the metaphors provided under seven conceptual categories as reached in the studyrepresent the conceptual category in question or not. For that purpose, the expert was given two lists: (a) a list on which the 119 sample metaphors are present in an alphabetical order and (b) a list that contained the names and properties of the seven different conceptual categories. The expert was asked to match the sample metaphors on the first list with the seven conceptual categories on the second list (in the manner that no metaphor would be excluded). Later on, the matches performed by the expert were compared with the study's own categories. In the comparisons, the number of agreements and disagreements were determined and the reliability of the study was calculated by using the Reliability = agreements/ agreements + disagreements formula (Miles and Huberman, 1994).

In the qualitative studies, the desired level of reliability is ensured in the cases where the harmony between the expert and the researcher is $90 \%$ and above (Saban et al., 2006; Saban, 2009). The reliability of this study is $95 \%$. The expert whose opinion was asked in terms of reliability related five metaphors (Anatolia, silence of the lambs, axe, sugar, half-time in a game) by including in a different category from that of the researcher. In this case, the calculation was Reliability $=119 /(119+5)=0.95$.

5. Phase of Transferring Data to Computer: Subsequent to the determination of the total 119 metaphors and to the development of the seven conceptual categories created by those metaphors, entire data were transferred to the SPSS statistics program. Following that process, the number of the participants (n) and their percentage (\%) representing the 119 metaphors and seven categories have been calculated.

\section{Findings}

In this section, the findings obtained in relation with the metaphors developed by the Sports Sciences Faculty students for the concept of "Fair-Play" are presented in the form of tables and construed by analyzing as subheadings in line with the questions of the study.

\section{Findings for the Metaphors of the Sports Sciences Faculty Students regarding the Concept of "Fair-Play"}

Students have produced totally 119 valid metaphors regarding the concept of "Fair Play."73 of the total 119 metaphors were produced by only one participant. They are step, painkiller, bulb, Anatolia, treaty, axe, infectious disease, sap, Çanakkale, flower, revolution, true word, doctor, domino, helping the needy, empathy, male, self-sacrifice, philosophy, flashlight, idea, rainbow, power, rose, beauty, arrow shot at a target, $\mathrm{Hz}$. Ömer, worship, instinct, cheating and passion, two edged knife, spring, fortress, law, snow, butterfly, self-abnegation, red light, running, silence of the lambs, half-time 
in a game, mercy, valor, happiness, virtue, ocean, maturity, indicator of honor, revitalizing the dead, freedom, sharing, compass, advertisement, dream, wind, loyalty, joy, warm ambiance, duster, politics, the wind blowing in autumn, character of a sportsperson, waterfall, tactic, history, scales, slap, conscience, rain, leaf, healing a wounded enemy soldier, food, and Yunus Emre.

Remaining metaphors vary between two to 11 participants. They are the moon, generosity, sea, nature, education, equality, night, judge, drug, goodness, Mustafa Kemal Ataturk, teacher, spirit, soap, being respectful, sugar, utopia $(n=2)$; justice, family, fellowship, peace, baby, gentlemanliness, honesty, sky, life, Hz. Mevlana, human nature, humanity, Islamic religion, woman, book, angel, love $(n=3)$; tree, morality, soil, olive branch $(n=4)$; romantic love ( $n=6)$, friendship, brotherhood ( $n=8)$; father-mother, white page, the sun $(n=9)$; mirror, and water $(n=11)$. As it is seen, numerous metaphors were used by the participants regarding the concept of "Fair Play."

Table 2. The Valid Metaphors Developed by the Sports Sciences Faculty Students for the Concept of "Fair-Play" and the Number of the Participants Representing them (in Alphabetical Order) and their Percentage

\begin{tabular}{|c|c|c|c|c|c|c|c|}
\hline \multirow{2}{*}{ 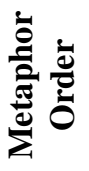 } & \multirow{2}{*}{ Metaphor Name } & \multicolumn{2}{|c|}{ Frequency Percentage } & \multirow{2}{*}{ 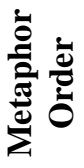 } & \multirow{2}{*}{ Metaphor Name } & \multirow{2}{*}{$\begin{array}{c}\text { Frequency } \\
\text { (f) }\end{array}$} & \multirow{2}{*}{$\begin{array}{c}\text { Percentage } \\
(\%)\end{array}$} \\
\hline & & (f) & $(\%)$ & & & & \\
\hline 1 & Justice & 3 & 1,22 & 61 & Humanity & 3 & 1,22 \\
\hline 2 & Step & 1 & 0,41 & 62 & Islamic religion & 3 & 1,22 \\
\hline 3 & Tree & 4 & 1,62 & 63 & Goodness & 2 & 0,82 \\
\hline 4 & Painkiller & 1 & 0,41 & 64 & Woman & 3 & 1,22 \\
\hline 5 & Morality & 4 & 1,62 & 65 & Fortress & 1 & 0,41 \\
\hline 6 & Family & 3 & 1,22 & 66 & Law & 1 & 0,41 \\
\hline 7 & Bulb & 1 & 0,41 & 67 & Snow & 1 & 0,41 \\
\hline 8 & Anatolia & 1 & 0,41 & 68 & Fraternity & 8 & 3,26 \\
\hline 9 & Father-mother & 9 & 3,66 & 69 & Butterfly & 1 & 0,41 \\
\hline 10 & Treaty & 1 & 0,41 & 70 & Self-abnegation & 1 & 0,41 \\
\hline 11 & Fellowship & 3 & 1,22 & 71 & Red light & 1 & 0,41 \\
\hline 12 & Romantic love & 6 & 2,45 & 72 & Book & 3 & 1,22 \\
\hline 13 & The moon & 2 & 0,82 & 73 & Running & 1 & 0,41 \\
\hline 14 & Mirror & 11 & 4,48 & 74 & Silence of the lambs & 1 & 0,41 \\
\hline 15 & Axe & 1 & 0,41 & 75 & Half-time in a game & 1 & 0,41 \\
\hline 16 & Peace & 3 & 1,22 & 76 & Angel & 3 & 1,22 \\
\hline 17 & Baby & 3 & 1,22 & 77 & Pity & 1 & 0,41 \\
\hline 18 & White page & 9 & 3,66 & 78 & Valor & 1 & 0,41 \\
\hline 19 & Infectious disease & 1 & 0,41 & 79 & Mustafa Kemal Ataturk & 2 & 0,82 \\
\hline 20 & Sap & 1 & 0,41 & 80 & Happiness & 1 & 0,41 \\
\hline 21 & Gentlemanliness & 3 & 1,22 & 81 & Virtue & 1 & 0,41 \\
\hline 22 & Generosity & 2 & 0,82 & 82 & Ocean & 1 & 0,41 \\
\hline 23 & Çanakkale & 1 & 0,41 & 83 & Maturity & 1 & 0,41 \\
\hline 24 & Flower & 1 & 0,41 & 84 & Indicator of honor & 1 & 0,41 \\
\hline 25 & Sea & 2 & 0,82 & 85 & Teacher & 2 & 0,82 \\
\hline 26 & Revolution & 1 & 0,41 & 86 & Revitalizing the dead & 1 & 0,41 \\
\hline 27 & Nature & 2 & 0,82 & 87 & Freedom & 1 & 0,41 \\
\hline 28 & True word & 1 & 0,41 & 88 & Sharing & 1 & 0,41 \\
\hline
\end{tabular}




\begin{tabular}{|c|c|c|c|c|c|c|c|}
\hline 29 & Doctor & 1 & 0,41 & 89 & Compass & 1 & 0,41 \\
\hline 30 & Domino & 1 & 0,41 & 90 & Advertisement & 1 & 0,41 \\
\hline 31 & Friendship & 8 & 3,26 & 91 & Spirit & 2 & 0,82 \\
\hline 32 & Honesty & 3 & 1,22 & 92 & Dream & 1 & 0,41 \\
\hline 33 & Helping the needy & 1 & 0,41 & 93 & Wind & 1 & 0,41 \\
\hline 34 & Education & 2 & 0,82 & 94 & Soap & 2 & 0,82 \\
\hline 35 & Empathy & 1 & 0,41 & 95 & Being faithful & 1 & 0,41 \\
\hline 36 & Male & 1 & 0,41 & 96 & Being respectful & 2 & 0,82 \\
\hline 37 & Equality & 2 & 0,82 & 97 & Love & 3 & 1,22 \\
\hline 38 & Self-devotion & 1 & 0,41 & 98 & Joy & 1 & 0,41 \\
\hline 39 & Philosophy & 1 & 0,41 & 99 & Warm ambiance & 1 & 0,41 \\
\hline 40 & Flashlight & 1 & 0,41 & 100 & Duster & 1 & 0,41 \\
\hline 41 & Idea & 1 & 0,41 & 101 & Politics & 1 & 0,41 \\
\hline 42 & Night & 2 & 0,82 & 102 & $\begin{array}{l}\text { The wind blowing in } \\
\text { autumn }\end{array}$ & 1 & 0,41 \\
\hline 43 & Rainbow & 1 & 0,41 & 103 & $\begin{array}{lll}\begin{array}{l}\text { Character } \\
\text { sportsperson }\end{array} & \text { of } & \text { a }\end{array}$ & 1 & 0,41 \\
\hline 44 & Sky & 3 & 1,22 & 104 & Water & 11 & 4,48 \\
\hline 45 & Power & 1 & 0,41 & 105 & Sugar & 2 & 0,82 \\
\hline 46 & Rose & 1 & 0,41 & 106 & Waterfall & 1 & 0,41 \\
\hline 47 & The sun & 9 & 3,66 & 107 & Tactic & 1 & 0,41 \\
\hline 48 & Beauty & 1 & 0,41 & 108 & History & 1 & 0,41 \\
\hline 49 & Judge & 2 & 0,82 & 109 & Scales & 1 & 0,41 \\
\hline 50 & Life & 3 & 1,22 & 110 & Slap & 1 & 0,41 \\
\hline 51 & Arrow shot at a target & 1 & 0,41 & 111 & Soil & 4 & 1,62 \\
\hline 52 & Hz. Mevlana & 3 & 1,22 & 112 & Utopia & 2 & 0,82 \\
\hline 53 & Hz. Ömer & 1 & 0,41 & 113 & Conscience & 1 & 0,41 \\
\hline 54 & Worship & 1 & 0,41 & 114 & Rain & 1 & 0,41 \\
\hline 55 & Instinct & 1 & 0,41 & 115 & Leaf & 1 & 0,41 \\
\hline 56 & Cheating and passion & 1 & 0,41 & 116 & $\begin{array}{l}\text { Healing a wounded enemy } \\
\text { soldier }\end{array}$ & 1 & 0,41 \\
\hline 57 & Two edged knife & 1 & 0,41 & 117 & Eating & 1 & 0,41 \\
\hline 58 & Drug & 2 & 0,82 & 118 & Yunus Emre & 1 & 0,41 \\
\hline 59 & Spring & 1 & 0,41 & 119 & Olive branch & 4 & 1,62 \\
\hline 60 & Human's self & 3 & 1,22 & & & & \\
\hline \multicolumn{6}{|c|}{ Total } & 245 (f) & $100(\%)$ \\
\hline
\end{tabular}




\section{The Categories Constituted by the Metaphors of the Students regarding the Concept of "Fair Play"}

The students' metaphors regarding the concept of "Fair Play"have been brought together in seven categories. They are Fair Play as the expression of wisdom, Fair Play as the expression ofnature, Fair Play as a Guide, Fair Play as the expression of humanly qualifications, Fair Play as the expression of cleanness,Fair Play as the expression of contradiction, and Fair Playas Important Persons. The categories of the students" metaphors for the concept of "Fair Play" are shown in Table 3 below.

Table 3. The Categories of the Metaphors of the Students regarding the Concept of "Fair Play"

\begin{tabular}{lcc}
\hline Categories & Metaphors & $\begin{array}{c}\text { Metaphor } \\
\text { Frequency of }\end{array}$ \\
Metaphors \\
the
\end{tabular}

Justice (3), morality (4), fellowship (3), peace (3), gentlemanliness (3), generosity (2), true word (1), friendship (8), honesty (3), helping the needy (1), empathy (1), equality (2), self-sacrifice (1), beauty

1. Fair Play as an Expression of Wisdom

(1), goodness (2), brotherhood (8), self-abnegation (1), half-time in a game (1), mercy (1), valor (1), happiness (1), virtue (1), maturity (1), indicator of honor (1), revitalizing the dead (1), freedom (1), sharing (1), being faithful (1), being respectful (2), love (3), joy (1), scales (1), conscience (1), healing a wounded enemy soldier (1)

Tree(4), Anatolia (1), the moon (2), flower (1), sea (2), nature (2), night (2), rainbow (1), sky (3), rose

2. Fair Play as an Expression of Nature

(1), the sun (9), life (3), spring (1), fortress (1), snow

(1), butterfly (1), silence of the lambs (1), ocean (1), wind (1), the wind blowing in autumn (1), water (11), waterfall (1), soil (4), rain (1), leaf (1), olive branch (4)

Step (1), painkiller (1), bulb (1), treaty (1), romantic love (6), mirror (11), infectious disease (1), sap (1), revolution (1), domino (1), education (2), philosophy

3. Fair Play as a Guide (1), flashlight (1), idea (1), power (1), arrow shot at a target (1), drug (2), law (1), book (3), running (1), compass (1), advertisement (1), spirit (2), tactic (1), history (1), eating (1)

Family (3), father-mother (9), baby (3), Çanakkale

4. Fair Play as an Expression of (1), doctor (1), male (1), judge (2), human nature (3), Humanly Qualifications humanity (3), woman (3), teacher (2), warm ambiance (1), character of a sportsperson (1),

\begin{tabular}{llll}
\hline $\begin{array}{l}\text { 5. Fair Play as an Expression of } \\
\text { Cleanness }\end{array}$ & $\begin{array}{l}\text { Axe (1), white page (9), worship (1), Islamic religion } \\
\text { (3), angel (3), soap (2), duster (1), }\end{array}$ & 20 & 7 \\
\hline $\begin{array}{l}\text { 6. Fair Play as an Expression of } \\
\text { Contradiction }\end{array}$ & $\begin{array}{l}\text { Instinct (1), cheating and passion (1), two-edged knife } \\
\text { (1), red light (1), dream (1), politics (1), sugar (2), slap } \\
\text { (1), utopia (2) }\end{array}$ & 11 & 9 \\
\hline $\begin{array}{l}\text { 7. Fair Play as Important } \\
\text { Persons }\end{array}$ & $\begin{array}{l}\text { Hz. Mevlana (3), Hz. Ömer (1), Mustafa Kemal } \\
\text { Ataturk (2), YunusEmre (1) }\end{array}$ & 7 & 4 \\
\hline Total & & $\mathbf{2 4 5}$ & $\mathbf{1 1 9}$ \\
\hline
\end{tabular}




\section{Conceptual Categories}

Category 1. Fair Play as an Expression of Wisdom: in this category constituted by those who identify Fair Play with wisdom and perceive the wisdom that are in the center of the moral behaviors as Fair Play, 34 metaphors and 67 participants (27\%) are present. In view of the frequency distribution (number of the participants) of the metaphors in this category, the most frequently used ones are brotherhood $(n=8)$, friendship $(n=8)$, morality $(n=4)$, justice $(n=3)$, fellowship $(n=3)$, peace $(n=3)$, gentlemanliness $(n=3)$, honesty $(n=3)$, love $(n=3)$, generosity $(n=2)$, equality. $(n=2)$, goodness ( $n=2)$, being respectful $(n=2)$, true word $(n=1)$, helping the needy $(n=1)$, empathy $(n=1)$, self-sacrifice $(n=1)$, beauty $(n=1)$, self-abnegation $(n=1)$, half-time in a game $(n=1)$, mercy $(n=1)$, valor $(n=1)$, happiness $(n=1)$, virtue $(n=1)$, maturity $(n=1)$, indicator of honor $(n=1)$, revitalizing the dead $(n=1)$, freedom $(n=1)$, sharing $(n=1)$, being faithful $(n=1)$, joy $(n=1)$, scales $(n=1)$, conscience $(n=1)$, healing a wounded enemy soldier $(n=1)$ respectively. The expressions of some of the participants in this category are provided below.

"Fair play is like brotherhood because you do not discriminate between your competitor and your sibling."

"Fair play is like brotherhood because it provides us with warmness, unity, and togetherness."

"Fair play is like friendship because it shows us what is right and what is wrong."

"Fair play is like morality because it present in the nature and character of a person."

"Fair play is like justice because it represents honesty and integrity."

"Fair play is like fellowship because it is the behavior without considering interests and with respect, tolerance, harmony, and justice."

"Fair play is like love because there is no lie and fraud in love."

"Fair play is like revitalizing the dead because it revitalizes the dead respect, love, and tolerance."

"Fair play is like conscience because it is the direction you choose when you are stuck between winning and conscience."

"Fair play is like healing the wounded enemy soldier because the healing solider does not have that spirit that much. He/she will not be beside you when you are wounded but you relieve by conscience when you heal that soldier and winning becomes more meaningful."

Category 2. Fair Play as an Expression of Nature: in this category constituted by those who identify Fair Play with nature and perceive the cleanness and purity of nature as Fair Play, 26 metaphors and 61 participants (25\%) are present. In view of the frequency distribution (number of the participants) of the metaphors in this category, the most frequently used ones are water $(n=11)$, the sun $(n=9)$, tree $(n=4)$, soil $(n=4)$, olive branch $(n=4)$, sky $(n=3)$, life $(n=3)$, the moon $(n=2)$, sea $(n=2)$, nature $(n=2)$, night $(n=2)$, Anatolia $(n=1)$, flower $(n=1)$, rainbow $(n=1)$, rose $(n=1)$, spring $(n=1)$, fortress $(n=1)$, snow $(n=1)$, butterfly $(n=1)$, silence of the lambs $(n=1)$, ocean $(n=1)$, wind $(n=1)$, the wind blowing in autumn $(n=1)$, waterfall $(n=1)$, rain $(n=1)$, leaf $(n=1)$ respectively. The expressions of some of the participants in this category are provided below.

"Fair play is like water because it is pure, lucid, and fluid."

"Fair play is like water because it is an indispensible factor in our lives."

"Fair play is like the sun because it warms up people."

"Fair play is like the sun because it sheds light on humans with its existence."

"Fair play is like a tree because everyone can make use of its fruits."

"Fair play is like a tree because it yields beautiful fruits."

"Fair play is like soil because it is the same concept for everyone."

"Fair play is like an olive branch because it tells us the tolerance in different societies."

"Fair play is like the sky because it brings together every nation, every language, and every religion under a single roof."

"Fair play is like the moon because it teaches how to shine in darkness."

"Fair play is like flower because it leaves one with good memories in every honest behavior."

"Fair play is like a wind because it gives a different air as it blows."

"Fair play is like a rain because it is good to be soaked." 
Category 3. Fair Play as a Guide: in this category constituted by those who consider Fair Play as a Guide, 26 metaphors and 46 participants (19\%) are present. In view of the frequency distribution (number of the participants) of the metaphors in this category, most frequently used ones are mirror $(n=11)$. romantic love $(n=6)$, book $(n=3)$, education ( $n=2)$, drug $(n=2)$, spirit $(n=2)$, step $(n=1)$, painkiller $(n=1)$, bulb $(n=1)$, treaty $(n=1)$, infectious disease $(n=1)$, sap $(n=1)$, revolution $(n=1)$, domino $(n=1)$, philosophy $(n=1)$, flashlight $(n=1)$, idea $(n=1)$, power $(n=1)$, arrow shot at a target $(n=1)$, law $(n=1)$, running $(n=1)$, compass $(n=1)$, advertisement $(n=1)$, tactic $(n=1)$, history $(n=1)$, and eating $(n=1)$ respectively. The expressions of some of the participants in this category are provided below.

"Fair play is like a mirror because the behavior of your competitor against you is determined by your behavior against him/her."

"Fair play is like a mirror because it reflects the personality of someone."

"Fair play is like romantic love because it depicts love."

"Fair play is like romantic love because mutual love necessitates respect."

"Fair play is like romantic love because it gains meaning as long as it is given value."

"Fair play is like a book because it teaches people the good, the right, and what a sportsperson must be like."

"Fair play is like education because the horizon of a person enlarges as long as he/she becomes knowledgeable."

"Fair play is like a drug because it treats the soul of a person in the most difficult times."

"Fair play is like a bulb because it sheds light on humanity."

"Fair play is like an infectious disease because a favor done invokes the same senses in the counterparty and causes him/her to behave in the same way toward competitors."

"Fair play is like domino because all its beauty will disappear when even one of them is aligned wrongly."

"Fair play is like an arrow shot at a target because you show your objective regardless of whether you hit the target or not."

"Fair play is like a compass because it shows the truth at all times."

Category 4. Fair Play as an Expression of Humanly Qualifications: in this category constituted by those who consider Fair Play as the expression of the humanly qualifications, 13 metaphor and 33 participants (13\%) are present. In view of the frequency distribution (number of the participants) of the metaphors in this category, the most frequently used ones are father-mother $(n=9)$, family $(n=3)$, baby $(n=3)$, human nature $(n=3)$, humanity $(n=3)$, woman $(n=3)$, teacher $(n=2)$, judge $(n=2)$, Çanakkale $(n=1)$, doctor $(n=1)$, male $(n=1)$, warm ambiance $(n=1)$, and character of a sportsperson $(n=1)$ respectively. The expressions of some of the participants in this category are provided below.

"Fair play is like father-mother because it wishes no injustice through equal distribution between two children."

"Fair play is like father-mother because it is an example of unrequited love."

"Fair play is like family because it gives happiness and peace."

"Fair play is like a baby because it is unaware of anything, pure, clean, popular with everything it has, the most innocent, and source of happiness."

"Fair play is like humanness because today I need it and tomorrow someone else does."

"Fair play is like a woman because it attracts one to her."

"Fair play is like a teacher because it teaches us what is right and what is wrong."

"Fair play is like a judge because it represents the truth, wrong, righteousness, guilty, and equality."

"Fair play is like Çanakkale because it is giving of water to the enemy in the middle of a war."

Category 5. Fair Play as an Expression of Cleanness: in this category constituted by those who consider Fair Play as the expression of cleanness, seven metaphors and 20 participants (8\%) are present. In view of the frequency distribution (number of the participants) of the metaphors in this category, the most frequently used ones are white page $(n=9)$, Islamic religion $(n=3)$, angel $(n=3)$, soap $(n=2)$, axe $(n=1)$, worship $(n=1)$, and duster $(n=1)$ respectively. The expressions of some of the participants in this category are provided below. 
"Fair play is like a white page because it is cleanness, pureness, and good thinking."

"Fair play is like a white page because it means purity and cleanness."

"Fair play is like Islamic religion because it gives one peace."

"Fair play is like an angel because it represents goodness and what is right."

"Fair play is like soap because it shows the cleanness of a person."

"Fair play is like worship because one finds peace as long as he/she practices it."

Category 6. Fair Play as an Expression of Contradiction: in this category constituted by those who consider Fair Play as the expression of contradiction, nine metaphors and 11 participants (5\%) are present. In view of the frequency distribution (number of the participants) of the metaphors in this category, the most frequently used ones are sugar $(n=2)$, utopia $(n=2)$, instinct $(n=1)$, cheating and passion $(n=1)$, two-edged knife $(n=1)$, red light $(n=1)$, dream $(n=1)$, politics $(n=1)$, and $\operatorname{slap}(n=1)$ respectively. The expressions of some of the participants in this category are provided below.

"Fair play is like sugar because the life will not have a taste without it."

"Fair play is like utopia because its practice or reaching it is impossible."

"Fair play is like instinct because it emerges depending on one's circumstances at that moment."

"Fair play is like two-edged knife because a favor we have done might be considered stupidity by the supporters and teammates despite the world's opinion on it as a cool and nice behavior."

"Fair play is like a red light because it is practiced when thought of but not taken into account much in practice."

"Fair play is like politics because people are far away from tolerance when their interests are in question."

"Fair play is like a slap because it sometimes lowers the boom on people and sometimes softens them like the compassion of a mother."

Category 7. Fair Play as Important Persons: in this category constituted by those who identify Fair Play with important persons, four metaphors and seven participants (3\%) are present. In view of the frequency distribution (number of the participants) of the metaphors in this category, the most frequently used ones are $\mathrm{Hz}$. Mevlana ( $\mathrm{n=3}$ ), $\mathrm{Hz}$. Ömer $(n=1)$, Mustafa Kemal Ataturk (n=2), and YunusEmre $(n=1)$ respectively. The expressions of some of the participants in this category are provided below.

"Fair play is like Hz. Mevlana because it teaches us tolerance."

"Fair play is like Hz. Mevlana because it has all beauties in it."

"Fair play is like Hz. Ömer because it ensures us to play a game in justice."

"Fair play is like Mustafa Kemal Ataturk because it is present only in noble spirits."

"Fair play is like YunusEmre because a favor done is not expected to be appreciated by others in any case."

\section{Discussion and Conclusion}

This study has been conducted to reveal the metaphors of the Sports Sciences Faculty students regarding the concept of "Fair Play" and bring together those metaphors under some particular conceptual categories. The findings of this study draw attention to a few significant points.

First of all, numerous metaphors are needed for explaining the concept of "Fair-Play" in a holistic manner. The students that constitute the study group have produced 119 different metaphors for the concept of "Fair Play." For the concept of fair play, the students used various metaphors such as "mirror," "water," "white page," "the sun," "friendship," "brotherhood," "romantic love," "morality," "family," "gentlemanliness," and "Hz. Mevlana." This situation shows that it is not possible to explain the concept of "Fair Play"as a whole with a single metaphor. This result is supported by the expression of Weade and Ernst (1990), "Metaphors are selective and they represent a part, but not the whole, of the phenomena they describe," in which they attempt to express metaphors' power of describing a particular concept. In addition, Yob's (2003) statement of "Basically, metaphor is not the case it mentions, it is only an image. If it were the case, metaphor would not be required. Therefore, metaphor is different from the case, although it provides a very strong perspective related to the case, it is often less. It is necessary to utilize many metaphors to compensate such situation," supports our result and demonstrates the clarity of the need for alternative metaphors in order to explain particular 
abstract and complex phenomena as a whole.

In the second phase of the study, metaphoric perceptions of the students regarding the concept of "Fair Play" have been separated into conceptual categories. It appears that on this stage, the category where most metaphors are present is "Fair Play as an Expression of Wisdom." 27\% of the students have identified Fair Play with wisdom that is at the center of moral behaviors. It was followed respectively by the categories of "Fair Play as an Expression of Nature" by $25 \%$; "Fair Play as a Guide" by 19\%; "Fair Play as an Expression of Humanly Qualifications" by 13\%; "Fair Play as an Expression of Cleanness" by 8\%; "Fair Play as an Expression of Contradiction" by 5\%; and "Fair Play as Important Persons" by $3 \%$.

Fair play is in fact a concept in English. However, this concept with which everyone in relation with sports is familiar is known as "gentlemanliness" in almost everywhere from Spain to Germany, from India to Korea, from the African countries to the little Australian provinces (Erdemli, 1996). The use of the word is highlighted as the adherence to rules, respect to the management and its decisions, and respect to the contestants. In addition, Fair Play is used in relation with being generous in a game and exhibiting temperate manners either in success or in defeat (Loland, 2002).

Upon the entry of the concept of Fair Play into the Turkish language, various words were used as the translation of it. The behaviors that suit Fair Play are expressed generally by gentlemanliness,sportsmanship, or politeness (Koç and Tamer, 2016). The first source in which the concept of Fair Play was used directly and which is related completely with Fair Play is the work titled "SpordaErdemlik-Fair Play" (Ateşoğlu, 1974) sponsored to be translated and published by the Ministry of Youth and Sports in 1994. This way, the concept of Fair Play has entered the literature as "spordaerdemlik (wisdom in sports)" in Turkish and subsequently, the use of "sportiferdem (sportive wisdom)" was adopted (Erdemli, 1992). In recent years there has been an increase in the use of the word "sportsmanship", especially in the field of education (Koç, 2013).

No doubt, scopes of concepts depend on the meanings given to them in the course of a process. The concepts suggested as the meanings of Fair Play in Turkish appear to be highly far from the richness of Fair Play in terms of meaning. In an analysis of the articles regarding Fair Play in the German language, Rahe (1987) determined that the coverage area of the concept is fairly large in the spectrum of social courses of action.

In a published study regarding the determination of the concepts that might have the meaning of Fair Play in the Turkish language, even a part of the concepts listed by the university students studying in various departments is interesting in terms of reflecting the wealth of meanings denoting Fair Play:

Frankness, justice, morality, humbleness, understanding, friendship, forgiveness, loyalty, peace, deserving success, selflessness, consciousness, unity-togetherness, integration, acting as adults, gentility, avoidance of interests, solidarity, perfect behavior, valuing, attentive behavior, discipline, integrity, amicable playing, honesty, honest play, thoughtfulness, proper sports, acting as a gentleperson, wisdom, avoidance of fanaticism, self-sacrifice, avoidance of bad movements, equality of opportunity, credibility, beauty, fair behavior, avoidance of insults, righteousness, avoidance of cheating the referee, dignity, tolerance, belief, polite soul, mercy, humanly traits, humanism, good manners, optimism, goodwill, good character, brotherhood, self-control, kindness, avoidance of grudging, avoidance of saying bad words, obeying rules, coming to terms without needing rules, civil behavior, valor, perfection, courtesy, virtue, maturity, honorable behavior, temperateness, freedom, self-sacrifice, sharing, avoidance of considering the competitor as an enemy, spiritual beauty, patience, sincerity, respect, prestige, tenderness, love, cool-headedness, acceptance of results, loyalty to sports, protection of sportspeople, loving of sports, sportsmanship, rejection of violence, decency, coherent behavior, civilized behavior, harmony, helping, and learning to how to defeat and get defeated (Yıldiran, 2004).

As it is seen, the expansion of this concept to which everyone ascribes good meanings in the entire world theoretically but which appears to be overlooked when it comes to practice will be important in the elimination of complications emerging in the sportive environments. The understanding of Fair Play is not one of the traits that a person possesses inherently. It can be acquired upon a process of training performed in line with the goal (Y1ldiran, 2004). Accordingly, it appears when the metaphors of the students receiving sports education regarding the concept of "Fair Play" are scrutinized that the mostly preferred metaphors are mirror $(n=11)$, water $(n=11)$, mother-father $(n=9)$, white page $(n=9)$, and the sun ( $n=9)$. This situation demonstrates that the students have perceived "Fair Play" mainly as the reflection of the character of a person, an indispensible part of human life, selfless love, good thinking, and a concept that sheds light on humans with its existence; that is to say, indispensible elements of the moral values of a person.

As a result, the findings of this study harbor clues to reveal the manner of the students' perception of "Fair Play." Accordingly, metaphors can be used as powerful tools of research to understand, reveal, and interpret the mental images of the participants for the phenomenon of Fair Play. In addition, the findings of the study are considered significant instruments in teaching the humanly values and awareness of rules. As Gillis and Johnson (2002) states, metaphors “. . . help us understand the sense of self that we want to be or that we failed to be, that we have been and avoid being, and 
that we can even be." According to Saban et al (2006) and Yob (2003), it will be appropriate to use metaphors in the issues that are difficult to be understood. Metaphors can be alive-lifeless, abstract-concrete, and positive or negative. Metaphors can also be the tools of gathering and inquiring information. At the same time, metaphors ensure easier understanding of the issues that have not been understood sufficiently. In addition, they play a significant role in bringing problems to the surface in a clear manner and, most importantly, they ensure summarization of thoughts.

These metaphors will present new viewpoints to researchers as a significant guide when it comes to the termination of setbacks in sports in general and at the point of considering the competitor a partner who ensures the realization of a game as well as friendship and brotherhood in particular. Mental images are considered necessary to teach the extent of importance of this concept to sportspeople and individuals. It appears that because of the significance of its content, it is important to use it as a primary tool in the explanation of "Fair Play" by means of metaphors. In consideration of this idea, conduct of similar studies on the people doing sports actively is suggested. Likewise, sports educators performing their assignments at universities and state institutions can also be included in such studies. The metaphors coming to the surface in this study and the listed metaphors can be used as a source for the researchers who are to be preparing lists of Likert-type scales. It is possible to make use of the study when drawing up the curricula in the trainings regarding Fair Play.

\section{References}

Alger, C. (2009). Secondary teachers' conceptual metaphors of teaching and learning: Changes over the career Span. Teaching and Teacher Education: An International Journal of Research and Studies, 25(5), 743-751. https://doi.org/10.1016/j.tate.2008.10.004

Arslan, M. M., \& Bayrakçı, M. (2006). Metaforik düşünme ve öğrenme yaklaşımının eğitim-öğretim açısından incelenmesi. MilliEğitim, 35(171), 100-108.

Ateşoğlu, M. (1974). Sporda erdemlik-Fair play. Gençlik ve Spor Bakanlığı Yayın No: 29. Ankara.

Aydın, F., \& Ünaldı, Ü. E. 2010). The analysis of geography teacher candidates' perceptions towards "geography" concept with the help of metaphors. International Online Journal of Educational Sciences, 2(2), 600-622.

Botha, E. (2009). Why metaphor matters in education. South African of Education, 29, 431-444.

Çapan, E. B. (2010). Teacher candidates' metaphoric perceptions of gifted students.The Journal of International Social Research, 3(12), 140-154.

Cerit, Y. (2008). Öğretmen kavramı ile ilgili metaforlara ilişkin öğrenci, öğretmen ve yöneticilerin görüşleri. The Journal of Turkish Educational Sciences, 6(4), 693-712.

Çoşkun, M. (2010). Metaphors (mental images) of high school students about "climate" concept. International Periodical for the Languages, Literature and History of Turkish or Turkic, 5(3), 919-940.

Döş, İ. (2010). Metaphoric perceptions of candidate teachers to the concept of inspectors. Gaziantep University Journal of Social Sciences, 9(3), 607-629.

Erdemli, A. (1992). Fair play ve olimpizm. SporBilimleri II. Ulusal Kongresi Bildirileri (20-22 Kasım Hacettepe Üniversitesi, Ankara). SporBilimleri ve Teknolojisi Yayınları No:3, 180.

Erdemli, A. (1996). Insan, spor ve olimpizm. Sarmal Yayınevi, İstanbul.

Forceville, C. (2002). The identification of target and source in pictorial metaphors. Journal of Pragmatics, 34, 1-14. https://doi.org/10.1016/S0378-2166(01)00007-8

Gillis, C., \& Johnson, C. L. (2002). Metaphor as renewal: Re-imagining our professional selves. English Journal, 91(6), 37-43.https://doi.org/10.2307/821814

Guerrero, M. C. M., \& Villamil, O. S. (2002). Metaphorical conceptualizations of ELS teaching and learning.Language Teaching Research, 6(2), 95-120. https://doi.org/10.1191/13621688021r101oa

Kaya, H. (2011). The analysis of secondary education students' perceptions towards "the world" concept. World Applied Sciences Journal, 12(2), 190-196.

Koç, Y. (2013). Sportspersonship behavior scale in physical education course: Validity reliability study. Erzincan University Journal of Education Faculty, 15(1), 96-114.

Koç, Y., \& Tamer, K. (2016). A study on the sportsmanship behaviors of female students in physical education course according to different variables. Nigde University Journal of Physical Education and Sport Sciences, 7(1), 16-27.

Lakoff, G., \& Johnson, M. (2003). Metaphors we live by. The University of Chicago Press, London. https://doi.org/10.7208/chicago/9780226470993.001.0001 
Levine, P. M. (2005). Metaphors and images of classrooms. Kappa delta Pi Record, 41(4), 172-175. https://doi.org/10.1080/00228958.2005.10532066

Loland, S. (2002). Fair play in sport: A moral norm system. Routledge, London.

Miles, M. B., \& Huberman, A. M. (1994). Qualitative data analysis. Thousand Oaks, CA: Sage.

Öztürk, Ç. (2007). Metaphor status about the concept of "geography" of prospective social science, science and classroom teachers. Journal of Kurşehir Education Faculty (JKEF), 8(2), 55-69.

Rahe, B. (1987). Fair play in schule und erziehung. Schulverwaltungsblatt Niedersachsen, 3, 78.

Saban, A. (2004). Giriş düzeyindeki sınıf öğretmeni adaylarının "öğretmen” kavramına ilişkin ileri sürdükleri metaforlar. The Journal of Turkish Educational Sciences, 2(2), 131-155.

Saban, A. (2008). Primary school teachers' and their students' mental images about the concept of knowledge. Elemantary Education Online, 7(2), 421-455.

Saban, A. (2009). Öğretmen adaylarının öğrenci kavramına ilişkin sahip olduğu zihinsel imgeler. The Journal of Turkish Educational Sciences, 7(2), 281-326.

Saban, A., Koçbeker, B. N., \& Saban, A. (2006). An investigation of the concept of the teacher among prospective teachers through metaphor analysis. Educational Science: Theory\&Practice, 6(2), 461-522.

Shaw, D., Massengill, B., \& Mahlios, M. (2008). Preservice teachers' metaphors of teaching in relation to literacy beliefs. Teachers and Teaching: Theory and Practice, 14(1), 35-50. https://doi.org/10.1080/13540600701837632

Töremen, F., \& Döş, İ. (2009). The metaphoric perceptions of primary school teachers on the concept of inspection. Educational Science: Theory \& Practice, 9(4), 1973-2012.

Weade, R., \& Ernst, G. (1990). Pictures of life in classrooms, and the search for metaphors to frame them. Theory into Practice, 29(2), 133-140. https://doi.org/10.1080/00405849009543444

Yildiran, İ. (2004). Fair Play: Concept, view in Turkey and improving perspectives. Gazi Journal of Physical Education and Sports Sciences, IX(4), 3-16.

Yıldırım, A., \& Şimşek, H. (2006). Sosyal Bilimlerde Nitel Araştırma Yöntemleri, SeçkinYayınevi, Ankara.

Yıldırım, A., Ünal, A., \& Çelik, M. (2011). The analysis of principle's, supervisor's and teacher's perception of the term "teacher". Journal of Human Sciences, 8(2), 92-109.

Yob, I. M. (2003). Thinking constructively with metaphors. Studies in Philosophy and Education, 22, 127-138. https://doi.org/10.1023/A:1022289113443

\section{Copyrights}

Copyright for this article is retained by the author(s), with first publication rights granted to the journal.

This is an open-access article distributed under the terms and conditions of the Creative Commons Attribution license which permits unrestricted use, distribution, and reproduction in any medium, provided the original work is properly cited. 